\title{
Consumer profile and problems associated with uninspected raw milk consumption in western Paraná
}

\author{
Perfil dos consumidores e problemas associados \\ ao consumo de leite cru informal no oeste do Paraná
}

\author{
Nelson Kodama Lançoni Raymundo ${ }^{1 *}$, Luciano dos Santos Bersot ${ }^{1}$, Silvia Cristina Osaki ${ }^{1}$
}

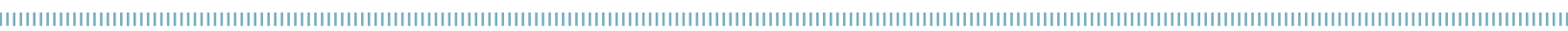

\begin{abstract}
The objectives of this study were to analyze consumer profile; to identify the main reasons for raw milk consumption; and to analyze in laboratory samples of uninspected raw milk from five towns in the western region of the state of Paraná, Brazil. The types of milk most frequently consumed were: $42.3 \%$ ultra-high temperature (UHT), $38.3 \%$ pasteurized milk, $17.6 \%$ uninspected raw milk, and $1.7 \%$ powered milk. The frequencies of households that preferred uninspected raw milk were, according to the town, $32.7 \%$ in Iporã, 29.2\% in Marechal Cândido Rondon, 18.9\% in Assis Chateaubriand, $17.6 \%$ in Palotina, and $10 \%$ in Toledo. Flavor was the main reason for uninspected raw milk consumption, and the purchase of this product was more frequent in households whose income was between one to four minimum wages. It was observed that the sales of uninspected milk are more financially advantageous to the producer than sales of inspected milk. All samples analyzed showed lack of compliance with at least one parameter, $60.9 \%$ for mesophilic counts, $56.6 \%$ for non-fat dry matter, $52.1 \%$ for freezing point, $43.5 \%$ for acidity, $23.9 \%$ for density, $23.9 \%$ for the casein macropeptide, $17.4 \%$ for fat content, $8.7 \%$ were reactors in the milk ring test, and $2.2 \%$ were reactors in microbial growth inhibitor test. Fraud by addition of water was observed in $20 \%$ of the samples. Uninspected raw milk analyzed in this study involved a low-quality product that is a financial hazard as it may be adulterated, and that poses risk to consumer health.
\end{abstract}

KEYWORDS: microbiological assay; milk; physical-chemical assay; ring test; inhibitor residues.
RESUMO: Os objetivos desta pesquisa foram verificar o perfil, identificar os principais motivos para o consumo e avaliar laboratorialmente as amostras de leite cru informal de cinco municípios do oeste do estado do Paraná, Brasil. Os tipos de leite mais frequentemente consumidos foram: $42,3 \%$ ultra-high temperature (UHT), $38,3 \%$ pasteurizado, $17,6 \%$ leite cru informal e 1,7\% em pó. As frequências de consumidores que preferiram leite cru informal, por cidade, foram: 17,6\% em Palotina, 29,2\% em Marechal Cândido Rondon, 18,9\% em Assis Chateaubriand, 17,6\% em Palotina e $10 \%$ em Toledo. Sabor foi o principal motivo que influenciou o consumo de leite cru informal, e famílias com renda familiar de um a quatro salários mínimos foram as que mais consumiram esse tipo de leite. A comercialização informal de leite foi mais vantajosa financeiramente para o produtor em relação à comercialização formal. Todas as amostras analisadas apresentaram-se em desacordo em pelo menos um parâmetro, sendo $60,9 \%$ para mesófilos, $56,6 \%$ para estrato seco desengordurado, 52,1\% para índice crioscópico, 43,5\% para acidez, $23,9 \%$ para densidade, $23,9 \%$ para índice de caseíno macropeptídeo, $17,4 \%$ para teor de gordura, $8,7 \%$ reagente ao teste do anel em leite (TAL), e 2,2\% reagente para presença de inibidor de crescimento bacteriano. A adulteração encontrada foi a adição de água em $20 \%$ das amostras analisadas. O leite cru informal avaliado nesta pesquisa envolveu a comercialização de um produto sem qualidade e que constitui um perigo financeiro, em razão do consumo de produtos adulterados, além do risco à saúde do consumidor.

PALAVRAS-CHAVE: ensaios microbiológicos; leite; ensaios físico-químicos; ring test, resíduos inibidores. 


\section{INTRODUCTION}

Milk is a very important food in human diet due to its high biological value, and it is a product of huge economic importance because of the diversity of products that can be made with it. However, milk constituents are very sensitive to microbial action, which affect its quality, and render it unsafe due to inadequate hygiene conditions in milking and processing (DÜRR et al., 2004).

Before processing, raw milk presents microbiological characteristics that are directly related to the health of the animal and hygiene of the milking procedure, showing a wide variation in microbial load. Therefore, milk may be a vehicle for zoonotic pathogens, such as Brucella abortus, enterotoxigenic Staphylococcus, Listeria monocytogenes (GUIMARÃES; LANGONI, 2009; CALLEFE; LANGONI, 2015) and tuberculosis, residues of veterinary drugs (BERSOT et al., 2010; COSTA; LOBATO, 2009; FOLLY; MACHADO, 2001; NERO et al., 2004; VIEIRA et al., 2012; VILLA; PINTO, 2008), and may be frauded by addition of water and reconstituants (BERSOT et al., 2010; VILLA; PINTO, 2008; SOVINSKI et al., 2014). Besides, unsafe, the lack of quality control management and hygiene inspection make uninspected raw milk a low quality and inadequate product that poses biological, chemical, and financial hazards to the consumers.

Commercialization of raw milk directly from the producer to the consumer is banned for more than 40 years by Regulation no. 923 from October $10^{\text {th }}, 1969$ (BRASIL, 1970). However, this kind of product is still found in the market due to the lack of information of producers and consumers who prefer to buy raw milk (ANTENORE, 1998) motivated by cultural issues and, recently, by erroneous conceptions spread on news related to frauds involving inspected milk that were not officially clarified, and occurred in the state of Rio Grande do Sul (ANTENORE, 1998; LENHARO; COUTINHO, 2013; MATOS, 2017). Nevertheless, the reasons for production and consumption of uninspected raw milk may be different throughout the country, justifying the need for studies in small regions to understand these motivations (NERO et al., 2003).

In this context, the objectives of this study were to analyze consumer profile, identifying the main reasons for raw milk consumption; and to evaluate parameters of physicalchemical and microbiological quality and the hazards that uninspected raw milk may pose in five towns in the western region of the state of Paraná, Brazil.

\section{MATERIAL AND METHODS}

This study was approved by the Research Ethics Committee (CEP) at Universidade Federal do Paraná (UFPR), Health Sciences Sector, protocol No. 433,687, from October 9 9 $^{\text {th }} 2013$.
The towns of Assis Chateaubriand, Iporá, Marechal Cândido Rondon, Palotina and Toledo, state of Paraná, were selected for the study. Populations of these towns were obtained from the 2010 demographic census (IBGE, 2010) and used to determine the population to be sampled. Sampling design took into account an expected prevalence of $50 \%$ in the consumption of uninspected raw milk, considering a design effect (DEFF) of 1.5; acceptable error of $5 \%$; and confidence interval of $95 \%$. Therefore, the sample was determined to be 647 interviews, proportionally distributed in each town according to their respective individual populations.

Interviews were performed in urban households of each town to determine the profile of households that were consumers of milk, and to identify those ones that preferred uninspected raw milk using a voluntary data questionnaire that was approved by the CEP of UFPR, Health Science Sector (protocol No. 433,687, from October $9^{\text {th }}$, 2013). This questionnaire was adapted from the model used by NERO et al. (2003) in Campo Mourão, Paraná, and designed for socioeconomic information on household consumption of milk, the knowledge of the interviewees about disease transmission and questions about the service inspection.

In households that accepted to take part in the study, participants signed an Informed Consent form that was approved by the CEP of UFPR. During the interviews, when the household was identified as consumer of uninspected raw milk, the researcher offered to purchase it, exchange it for inspected milk, or suggested a free analysis of uninspected milk.

Laboratory analyses were carried out in the Food and Water Inspection and Quality Control Laboratory (LACOMA) at the Veterinary Sciences Department of the UFPR, Palotina Sector. Microbiological and physical-chemical assays, analysis of inhibitor residues, somatic cell counts, and milk ring test were carried out in uninspected raw milk samples.

Microbiological analyses in raw milk were carried out according to Normative Instruction No. 62 of August $26^{\text {th }}, 2003$, from the Ministério da Agricultura, Pecuária e Abastecimento (BRASIL, 2003):

1. Thermotolerant coliform counts $(\mathrm{CFU} / \mathrm{mL})$;

2. Coagulase-positive Staphylococcus counts $(\mathrm{CFU} / \mathrm{mL})$;

3. Standard plate count of viable mesophilic counts $(\mathrm{CFU} / \mathrm{mL})$;

4. Presence or absence of Salmonella spp. in $25 \mathrm{~mL}$;

5. Presence or absence of Listeria monocytogenes in $25 \mathrm{~mL}$.

Physical-chemical analyses of uninspected raw milk were carried out according to Normative Instruction No. 68 of December 12 $2^{\text {th }}, 2006$ from the Ministério da Agricultura, Pecuária e Abastecimento (BRASIL, 2006b):

1. Titrable acidity;

2. Density at $15^{\circ} \mathrm{C}$;

3. Freezing point depression;

4. Fat content, total dry matter, and non-fat dry matter. 
Residues of inhibitors in milk, such as antimicrobial compounds, were carried out using the Delvotest kit (DSM Food Specialties Ingredients, Holland), according to the manufacturer's instructions.

Somatic cells counts (SCC) were determined with the commercial kit Somaticell (MADASA, São Paulo, Brazil), following the manufacturer's instructions.

The milk ring test (RT) was carried out according to the methodology described in Normative Instruction No. 41 of November 24 2006 from the Ministério da Agricultura, Pecuária e Abastecimento (BRASIL, 2006a).

Information gathered in the questionnaires were analyzed descriptively and comparatively using Tukey Test at 5\% probability in Statistical Analysis System (SAS) software. The statistical models involved the fixed effects of income, reasons, and type of milk.

\section{RESULTS AND DISCUSSION}

The 647 interviews in households that were consumers of milk in five towns showed that ultra-high temperature (UHT) milk was preferred in four of them: Assis Chateaubriand (53.3\%), Iporã (50\%), Palotina (43.5\%), and Marechal Cândido Rondon (40.8\%). In the city of Toledo, the major preference was related to pasteurized milk (50.3\%). Powdered milk was the least preferred product: Palotina (4.7\%), Marechal Cândido Rondon (1.7\%), Toledo (1.3\%), Assis Chateaubriand (1.1\%). In Iporã, powdered milk consumption was not recorded (Table 1).

A high variation coefficient was observed in the evaluation of the types of milk that was influenced by the information on the few households that consumed powdered milk. Because of it, data on these households were excluded in the parametric analyses to improve the analysis of data on the other types of milk and make it more consistent. However, information on these households was still used in descriptive analysis.

In Natal, Mossoró and Apodi, state of Rio Grande do Norte, Brazil, SOARES et al. (2010) found consumption frequencies of $29.5 \%$ for UHT, 26\% for pasteurized milk, $23.5 \%$ for uninspected raw milk, and $21 \%$ for powdered milk. In Cascavel, state of Paraná, UHT was preferred, with 50.3\% of the interviewees (ECKERT; ROMAN, 2010).

Table 1 also shows that consumption of informal raw milk in the five towns analyzed was: Iporã (32.7\%), Marechal Cândido Rondon (29.2\%), Assis Chateaubriand (18.9\%), Palotina (17.6\%), and Toledo (10\%). In Iporã and Marechal Cândido Rondon, consumption of uninspected raw milk was more frequent than pasteurized milk.

Among the reasons reported for preferring raw milk in this study (Table 2), flavor was the most important one, with statistical significance $(P>0.05)$. For example, in Iporã, 70.6\% households preferred to consume this type of product. One of the possible explanations of the better evaluation of the flavor

Table 1. Preferred type of milk in 647 interviews carried out from January to August 2013, according to the town.

\begin{tabular}{|c|c|c|c|c|c|}
\hline Toum & Interviews & Uninspected raw & Pasteurized & UHT & Powdered \\
\hline (8) & $\mathbf{n}$ & $\%$ & $\%$ & $\%$ & $\%$ \\
\hline Toledo & 300 & 10.0 & 51 & 37.7 & 1.3 \\
\hline Marechal Cândido Rondon & 120 & 29.1 & 37.5 & 41.7 & 1.7 \\
\hline Assis Chateaubriand & 90 & 18.9 & 26.7 & 53.3 & 1.1 \\
\hline Palotina & 85 & 17.6 & 34.1 & 43.5 & 4.7 \\
\hline Iporã & 52 & 32.7 & 27.3 & 50 & 0 \\
\hline Total & 647 & 17.6 & 38.3 & 42.3 & 1.7 \\
\hline
\end{tabular}

Table 2. Reasons for the preference for uninspected raw milk consumption $(n=114)$ in each town.

\begin{tabular}{|c|c|c|c|c|c|c|c|c|c|c|}
\hline \multirow{2}{*}{ Town } & \multicolumn{2}{|c|}{ Flavor } & \multicolumn{2}{|c|}{ Easy access } & \multicolumn{2}{|c|}{ Shelf-life } & \multicolumn{2}{|c|}{ Price } & \multicolumn{2}{|c|}{ Safety } \\
\hline & $\mathbf{n}$ & $\%$ & $\mathbf{n}$ & $\%$ & $\mathbf{n}$ & $\%$ & $\mathbf{n}$ & $\%$ & $\mathbf{n}$ & $\%$ \\
\hline Palotina & 8 & 53.3 & 4 & 26.7 & 1 & 6.6 & 2 & 13.3 & 0 & 0.0 \\
\hline Iporã & 12 & 70.6 & 3 & 17.6 & 0 & 0.0 & 2 & 11.8 & 0 & 0.0 \\
\hline Marechal Cândido Rondon & 19 & 54.3 & 9 & 25.7 & 1 & 2.8 & 5 & 14.3 & 1 & 2.8 \\
\hline Toledo & 16 & 53.3 & 2 & 6.7 & 1 & 3.3 & 10 & 33.3 & 1 & 3.3 \\
\hline Assis Chateaubriand & 9 & 52.9 & 1 & 5.9 & 1 & 5.9 & 5 & 29.4 & 1 & 5.9 \\
\hline Total & $64^{a}$ & 56.1 & $19^{b}$ & 16.7 & $4^{b}$ & 3.5 & $24^{b}$ & 21.0 & $3^{b}$ & 2.6 \\
\hline
\end{tabular}

Different letters in the same row show statistical differences $(P<0.05)$. 
may be related with milk fat: as the product is not homogenized, it is possible that fat influences its taste. More than $65 \%$ of the samples presented fat content above $3.5 \%$.

Besides homogenization, milk industrial processing is also based on standardization of fat content and thermal processing, making processed milk sensorially different from raw milk. Milk components, such as fat, provide creaminess and flavor to milk (WALSTRA et al., 2005). Standardization of fat content is carried out to make milk fits in commercial categories: whole, semi-skimmed, or skimmed milk. For the latter two types, part of the fat is removed from the product. Homogenization reduces the size of the fat globules promoting better dispersion of light and making the product whiter (ORDÓNEEZ et al., 2005). Therefore, industrial processing of milk leads to sensory changes in the raw material, justifying the preference observed in many households for uninspected raw milk.

Flavor was also the main reason for the preference for this kind of milk in state of Rio Grande do Norte (SOARES et al., 2010), with $40 \%$ of respondents consumers in Vale do Rio São Francisco, state of Pernambuco, Brazil, (LIRO et al., 2011), and 50\% in Palotina, state of Paraná (BERSOT et al., 2010).

Although not statistically significant, the reason better price was the second motivation for uninspected raw milk consumption in the cities of Toledo (33.3\%) and Assis Chateaubriand (29.4\%). Comparison of the price paid for uninspected raw milk with the net value paid to the producers of inspected raw milk, according to the Center for Advanced Studies in Applied Economics (CEPEA) of the College of Agriculture Luiz de Queiroz, in University of Sáo Paulo (USP), tabled in the same period of the study a mean difference of $30.6 \%$ between uninspected raw milk and inspected milk, evidencing financial advantages for the producer that traded the uninspected product.

Uninspected raw milk consumption was observed in all household income ranges, but it was statistically significant when household income ranged from one to four minimum wages.

As for the knowledge on possible pathogens transmitted by any type of milk, it was observed that most of the households did not have information on that issue: $93.3 \%$ in Marechal Cândido Rondon, 91.1\% in Assis Chateaubriand, $91 \%$ in Toledo, $78.8 \%$ in Iporã, and $64.7 \%$ in Palotina. Similar results were observed in Natal, Mossoró, and Apodi, state of Rio Grande do Norte; Vale do Rio São Francisco, state of Pernambuco; and Palotina, state of Paraná, by SOARES et al. (2010), LIRO et al. (2011), and BERSOT et al. (2010), respectively, who reported that $92,70.3$, and $75 \%$ of the households that consumed uninspected raw milk did not know the risks associated with the consumption of this type of product. PIERI et al. (2014) reported that consumption of uninspected raw milk may be related with the lack of knowledge of the potential risks associated with it.
Boiling milk was a habit identified in most of the families that preferred uninspected raw milk: $100 \%$ in Assis Chateaubriand and Iporã, $97.2 \%$ in Marechal Cândido Rondon, $96.7 \%$ in Toledo, and $86.7 \%$ in Palotina. This habit was also recorded in $95.8 \%$ of the households that consumed uninspected raw milk in Vale do Rio São Francisco, state of Pernambuco (LIRO et al., 2011); by $95.5 \%$ of the households that consumed uninspected raw milk in the study by SOARES et al. (2010), in Natal, Mossoró and Apodi, state of Rio Grande do Norte, and by $100 \%$ of the households in Palotina, state of Paraná (BERSOT et al., 2010).

Comparing the results obtained in the present study for the city of Palotina with the ones of BERSOT et al. (2010), it may be observed that there was a reduction from 38.3 to $17.6 \%$ in the proportion of consumers that preferred uninspected raw milk.

The proportion of households that consumed uninspected raw milk and did not know about a specific regulation that prohibits the trade of raw milk directly to the consumers was: 94.1\% in Assis Chateaubriand, 91.4\% in Marechal Cândido Rondon, $86.7 \%$ in Toledo, $66.6 \%$ in Palotina, and 58.8\% in Iporã. LIRO et al. (2011), in Vale do Rio São Francisco, Pernambuco, found that $91 \%$ consumers of uninspected raw milk did not know about the legal prohibition, similar to the results of the present study.

Models of the federal and state inspection services logos were presented to the interviewees, and $64.7 \%$ in Iporã, $51.4 \%$ in Marechal Cândido Rondon, $46.7 \%$ in Palotina, $41.2 \%$ in Assis Chateaubriand, and $40 \%$ in Toledo recognized these logos in milk packaging, but could not explain their importance in the safety and adequacy of inspected products. In the town of Viçosa, state of Minas Gerais, Brazil, PIERI et al. (2014) observed that only $37.2 \%$ of the interviewees knew the logos of the inspection services, posing a problem for the public health department.

Not all households that consumed uninspected raw milk agreed to exchange the product with the researcher for laboratory analysis. They said they were not interested or were concerned with causing problems to the producer. Therefore, from the 114 households that consumed informal raw milk, only 46 agreed to provide samples for the laboratory analysis, and $40.3 \%$ of the samples were analyzed.

Although illegal, raw milk was marketed directly to consumers in this study, and therefore the standards regulatory for trade (BRASIL, 2001) were applied for comparison with assay results.

All samples showed lack of compliance with at least one parameter: $60.9 \%$ for mesophilic counts, $56.6 \%$ for non-fat dry matter (NFDM), $52.1 \%$ for freezing point (FP), $43.5 \%$ for acidity, $23.9 \%$ for density, $8.7 \%$ were reactors in the ring test, and $2.2 \%$ were reactors for the presence of microbial growth inhibitors (Table 3 ). 
From the samples that did not comply with NFDM, $65.4 \%$ also presented $\mathrm{FP}$ above $0.530^{\circ} \mathrm{H}$, showing fraud by addition of water (Table 3). This type of fraud was also found in the studies of ALMEIDA et al. (1999) in Alfenas, Minas Gerais, and MENDES et al. (2010) in Mossoró, state of Rio Grande do Norte.

In the analysis of the FP, $47.8 \%$ of the samples did not comply with official regulations. In the studies carried out by ALMEIDA et al. (1999) in Alfenas, state of Minas Gerais, and MENDES et al. (2010) in Mossoró, state of Rio Grande do Norte, by CALDEIRA et al. (2010) in Janaúba, state of Minas Gerais, and by VILLA; PINTO (2008) in Brotas, state of Sáo Paulo, Brazil, 57.6, 50.0, 27.6 and 16.0\% of the samples of uninspected raw milk, respectively, did not comply with this parameter.

It was observed that $43.5 \%$ of the samples of uninspected raw milk were acid. From these ones, 55\% also presented mesophilic counts above $6.0 \times 10^{5} \mathrm{CFU} / \mathrm{mL}$. MENDES et al. (2010) and VILLA; PINTO (2008) found only 6.2 and 13.6\% of the samples that did not comply with this parameters in Mossoró, state of Rio Grande do Norte, and Brotas, state of São Paulo, respectively.

Mean mesophilic count recorded in the present study was $5.2 \times 10^{6} \mathrm{CFU} / \mathrm{mL}$, and $60.9 \%$ of the samples of uninspected raw milk did not comply with the regulation for this parameter. BERSOT et al. (2010) obtained mean mesophilic count higher than the ones of the present study $\left(4.6 \times 10^{7}\right.$ CFU/mL) in Palotina, state of Paraná, and VILLA; PINTO (2008), in Brotas, state of São Paulo, found 77.2\% of noncompliant samples. The high number of microorganisms associated with inadequate preservation of milk enable microbial growth, which is followed by the acidification of the product. Following the update of the national regulations for raw milk (BRASIL, 2016), if this study were conducted in 2016, $71.6 \%$ of milk samples would not comply with the parameter mesophilic count.

Coagulase-positive Staphylococcus involves species such as $S$. aureus and some species of $S$. intermedius, which have high potential for production of thermostable enterotoxin, responsible for foodborne diseases (LE LOIR et al., 2003). It is considered that counts between $10^{5}$ and $10^{6} \mathrm{CFU} / \mathrm{g} S$. aureus in food may produce enough enterotoxin to induce foodborne disease (FRANCO; LANDGRAF, 2008; MILIOTTIS; BIER, 2003). In the present study, $6.5 \%$ of the samples of uninspected raw milk analyzed presented counts above $10^{5} \mathrm{CFU} / \mathrm{mL}$, posing risk to the consumers of the product, even if it is boiled.

Although Salmonella spp. and L. monocytogenes were not detected in the samples of uninspected raw milk, $8.7 \%$ were positive in the ring test, showing risk of Brucella abortus transmission. The ring test is an important tool in the epidemiological vigilance of bovine brucellosis, and it is indicated as a method for presumptive diagnosis (SILVA JÚNIOR et al., 2007). ALMEIDA et al. (1999) did not found samples positive in the RT, in uninspected raw milk in Alfenas, state of Minas Gerais. On the other hand, SWAI; SCHOOMANN (2011) found $56 \%$ samples reactor to RT in the town of Tanga, in Tanzania. It should be clear that RT is a screening test that does not show the prevalence of $B$. abortus in a herd; the identification of infected animals requires individual serological tests.

In this study, it was observed that only one sample (2.2\%) showed residues of inhibitors in the Delvotest $\mathrm{SP}^{\circ}$ (DSM Food Specialties Ingredients, Holland). VILLA; PINTO (2008) and

Table 3. Results of the laboratory assays carried out in uninspected raw milk and non-compliance with official regulations: $n=46$; for SCC assay, $\mathrm{n}=18$.

\begin{tabular}{|c|c|c|}
\hline Assay & Average and standart deviation & Non-compliance (\%) \\
\hline Acidity ( $\left.{ }^{\circ} \mathrm{D}\right)^{* *}$ & $18.6 \pm 2.6$ & 43.5 \\
\hline Density at $15^{\circ} \mathrm{C}(\mathrm{g} / \mathrm{mL})^{* *}$ & $1.0290 \pm 0.0023$ & 23.9 \\
\hline Freezing point $\left({ }^{\circ} \mathrm{H}\right)^{* *}$ & $-0.520 \pm 0.033$ & 47.8 \\
\hline Fat $(\mathrm{g} / 100 \mathrm{~mL})$ ** & $3.74 \pm 1.00$ & 17.4 \\
\hline $\operatorname{NFDM}(g / 100 \mathrm{~g})^{* *}$ & $8.24 \pm 0.56$ & 56.6 \\
\hline \multicolumn{3}{|l|}{ Microbiology, inhibitors, SCC, RT } \\
\hline Mesophilic counts (CFU/mL)** & $5.2 \times 10^{6} \pm 9,3$ & 60.9 \\
\hline Staphylococcus C (+) (CFU/mL) $)^{\mathrm{NS}}$ & - & 6.5 \\
\hline Coliforms $45^{\circ} \mathrm{C}(\mathrm{CFU} / \mathrm{mL})^{*}$ & $2.3 \times 10^{4} \pm 4,2$ & 26.1 \\
\hline Salmonella sp. $(25 \mathrm{~mL})^{*}$ & Absence & 0.0 \\
\hline Listeria monocytogenes ${ }^{\mathrm{NS}}$ & Absence & 0.0 \\
\hline $\mathrm{SCC}(\mathrm{SC} / \mathrm{mL})^{* *}$ & $8.2 \times 10^{5} \pm 4,6$ & 72.2 \\
\hline $\mathrm{RT}^{* *}$ & Non Reagent & 8.7 \\
\hline Inhibitors** & Negative & 2.2 \\
\hline
\end{tabular}

*BRASIL (2001); **BRASIL (2011); NS: no official standard; SCC: somatic cells counts; RT: ring test. 
MOTTA et al. (2015), using the same kit, found 6 and 59\% of positive samples, respectively. This commercial test shows high sensitivity but low specificity as it does not identify the nature of the residue (antimicrobial or antiparasitic agent, disinfectants, detergent). However, it points out to chemical hazards in milk. This sample showed high mesophilic $\left(5.1 \times 10^{6} \mathrm{CFU} / \mathrm{mL}\right)$, total coliform $\left(1.5 \times 10^{4} \mathrm{CFU} / \mathrm{mL}\right)$, and somatic cell counts $\left(6.3 \times 10^{5} \mathrm{SC} / \mathrm{mL}\right)$. Thermotolerant coliforms and coagulase-positive Staphylococcus were not observed, as their growth may have been prevented by the inhibitor. However, all analyzed physical-chemical parameters were inside the range determined by official regulations (BRASIL, 2011). Because of that, the presence of antimicrobial residues in the sample may have been due to the treatment of cows for mastitis, given the high SCC and high microbial loads, which may be related do inadequate milk hygiene management.

SCC was carried out only in samples of uninspected raw milk from the towns of Toledo and Assis Chateaubriand $(\mathrm{n}=18)$. Comparing the adoption of region and time criteria established by Normative Instruction No. 62 from December $30^{\text {th }}, 2011$ (BRASIL, 2011), it was observed that $72.2 \%$ of the samples did not comply with the regulation, and mean of all counts was $8.2 \times 10^{5} \mathrm{SC} / \mathrm{mL}$, representing a possible loss in milk production ranging from 6 to $29 \%$, according to the National Mastitis Council (SANTOS; FONSECA, 2007). If this study were conducted in $2016,77.8 \%$ of the samples would be non-compliant with national regulations (BRASIL, 2016).

Last one, each sample was analyzed based on the overall set of laboratory assays. All samples showed some kind of non-compliance, with acid milk, high mesophilic counts, and addition of water as the most frequent problems (Fig. 1).

Addition of water was observed both as the single change in the sample and together with other changes (excess acidity, high microbial and somatic cell loads, defatting). Results shown in Figure 1 enabled us to infer that commercialization of uninspected raw milk in western Paraná poses financial risk to the families that prefer the product, as it is not standardized, and may possibly be defatted or have water added to it, besides its high acidity and microbial load. It also poses a health risk due to the possibility that part of the herd maybe sick, as shown by high somatic cell counts, samples reactor to the RT, and high counts of coagulase-positive Staphylococcus.

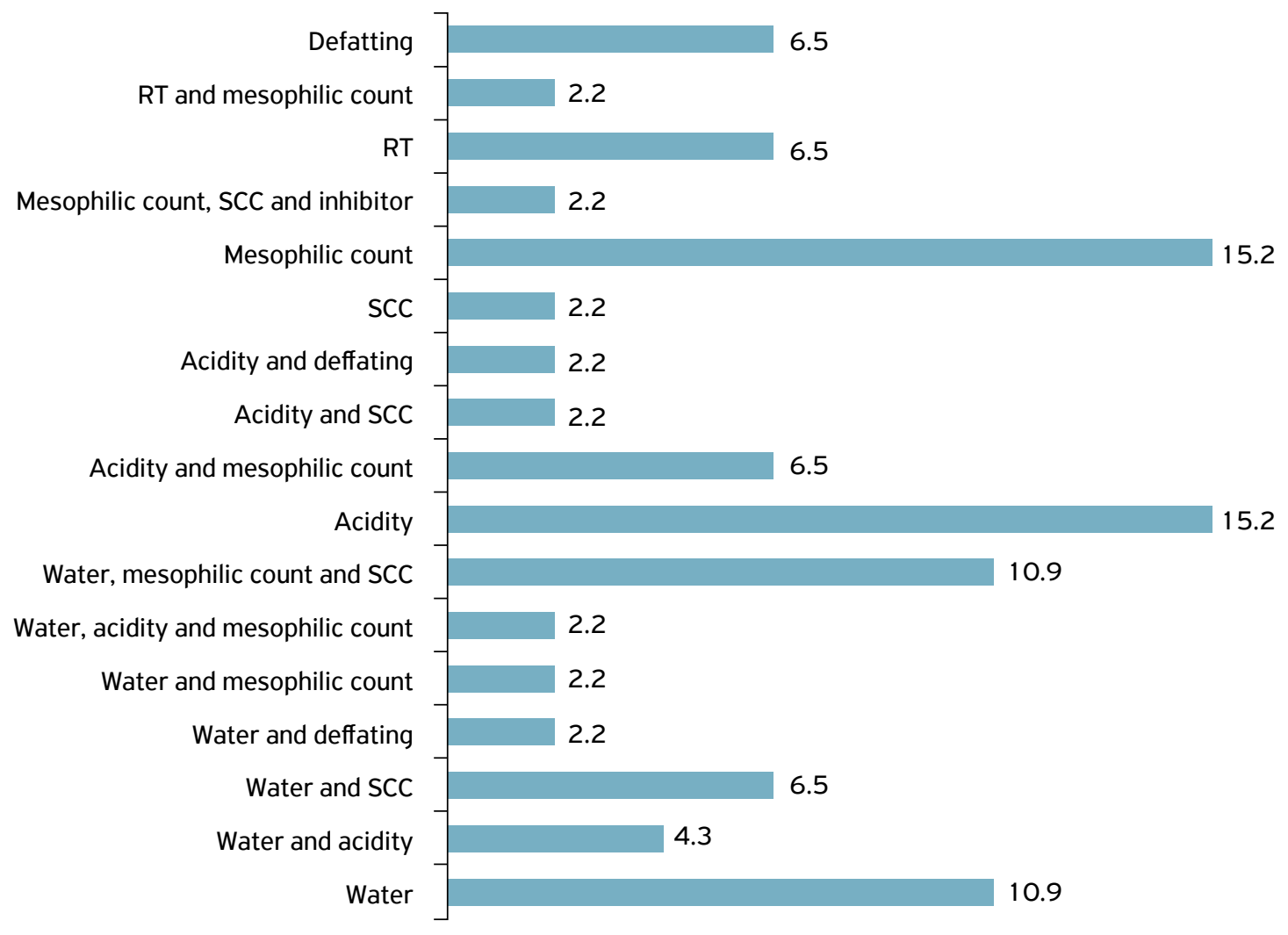

SCC: somatic cell counts above the official standard; inhibitor: milk reactor for the presence of inhibitors; RT: milk reactor in the ring test.

Figure 1. Inference on the status of all samples of uninspected raw milk analyzed $(n=46)$, based on the overall interpretation of the laboratory assays results. 


\section{CONCLUSIONS}

This study showed that uninspected raw milk is still commercialized in western Paraná, and that this kind of sale is more financially advantageous to the producer. The reasons for the survival of this kind of trade are the preference for the flavor and household income from one to four minimum wages. Other possible reasons that may contribute to the preference for the uninspected product are the lack of knowledge on possible biological hazards and health risk, on the importance of the consumption of inspected products, and on the existence of regulations banning this trade.

Besides, it was observed that this persistent commercialization leads to risks to the consumers due to fraud, lack of standardization, low quality and possible presence of pathogenic microorganisms in the product.

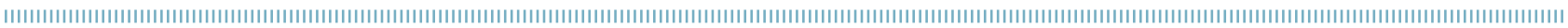
REFERENCES

ALMEIDA, A.C.; MOTA E SILVA, G.L.; DA SILVA, D.B.; FONSECA, Y.M.; BULETA, T.T.M.; FERNANDES, E.C. Características físicoquímicas e microbiológicas do leite cru consumido na cidade de Alfenas - MG. Revista Universidade Alfenas, Alfenas, v.5, p.165-168, 1999.

ANTENORE, A. $41 \%$ da produção de leite é clandestina. Folha de S.Paulo, p. 1-4, 1998. Caderno 3. Available from: <http://acervo. folha.com.br/fsp/1998/08/30/264//701 102>. Accessed on: 2012 May 12.

BERSOT, L.S.; DAGUER, H.; MAZIEIRO, M.T.; PINTO, J.P.A.N.; BARCELLOS, V.C.; GALVÃO, J.A. Raw milk trade: profile of the consumers and microbiological and physicochemical characterization of the product and in Palotina - Parana Region. Revista do Instituto de Laticínios Cândido Tostes, Juiz de Fora, v.65, n.373, p.3-8, 2010.

BRASIL. Ministério da Agricultura, Pecuária e Abastecimento. Instrução Normativa n. 7, de 03 de maio de 2016. Altera a tabela 2 do item 3.1.3.1. do Anexo II da Instrução Normativa n. 62 , de 29 de dezembro de 2011 , que aprova o Regulamento Técnico de Produção, Identidade e Qualidade do Leite tipo A, o Regulamento Técnico de Identidade e Qualidade de Leite Cru Refrigerado, o Regulamento Técnico da Coleta de Leite Cru Refrigerado e seu Transporte a Granel, passa a vigorar com a seguinte redação. Diário Oficial da União, n.84, p. 11 12 , May 42016.

BRASIL. Ministério da Agricultura, Pecuária e Abastecimento. Instrução Normativa n. 62, de 30 de dezembro de 2011 . Aprova o Regulamento Técnico de Produção, Identidade e Qualidade do Leite tipo A, Regulamento Técnico de Identidade e Qualidade de Leite Cru Refrigerado, o Regulamento Técnico de Identidade e Qualidade de Leite Pasteurizado e o Regulamento Técnico da Coleta de Leite Cru Refrigerado e seu Transporte a Granel, em conformidade com os Anexos desta Instrução Normativa. Diário Oficial da União, Dec. 302011.

BRASIL. Ministério da Agricultura, Pecuária e Abastecimento. Secretaria de Defesa Agropecuária. Instrução Normativa n. 41, de 24 de novembro de 2006. Aprova os "Critérios Específicos para o Credenciamento e Monitoramento de Laboratórios de Diagnóstico da Brucelose Bovina e Bubalina", na forma dos Anexos I a X à presente Instrução Normativa. Diário Oficial da União, Nov. 28 2006a.
BRASIL. Ministério da Agricultura, Pecuária e Abastecimento. Secretaria de Defesa Agropecuária. Instrução Normativa n. 62, de 26 de agosto de 2003. Oficializa os Métodos Analíticos Oficiais para Análises Microbiológicas para Controle de Produtos de Origem Animal e Água com seus respectivos capítulos e anexos. Diário Oficial da União, Sept. 182003.

BRASIL. Ministério da Agricultura, Pecuária e Abastecimento. Secretaria de Defesa Agropecuária. Instrução Normativa n. 68, de 12 de dezembro de 2006. Oficializa os Métodos Analíticos Oficiais Físico-Químicos, para Controle de Leite e Produtos Lácteos, em conformidade com o anexo desta Instrução Normativa, determinando que sejam utilizados nos Laboratórios Nacionais Agropecuários. Diário Oficial da União, Dec. 14 2006b.

BRASIL. Ministério da Saúde. Agência Nacional de Vigilância Sanitária. Resolução RDC n. 12, de 2 de janeiro de 2001 . Aprova o Regulamento Técnico sobre Padrões Microbiológicos para Alimentos. Diário Oficial da União, Jan. 102001.

BRASIL. Presidência da República. Ministério da Marinha de Guerra, do Exército e da Aeronáutica Militar. Decreto Lei Federal n. 66.183, de 5 de fevereiro de 1970. Regulamenta o Decreto-Lei n. 923, de 10 de outubro de 1969, que dispõe sobre a Comercialização do Leite Cru. Diário Oficial da União, Feb. 061970.

CALDEIRA, L.A.; ROCHA JÚNIOR, V.R.; FONSECA, C.M.; MELO, L.M.; CRUZ, A.G.; OLIVEIRA, L.L.S. Caracterização do leite comercializado em Janaúba - MG. Alimentos e Nutrição, Araraquara, v.21, n.2, p.191-195, 2010.

CALLEFE, J.L.R.; LANGONI, H. Qualidade do leite: uma meta a ser atingida. Veterinária e Zootecnia, Botucatu, v.22, n.2, p.151$161,2015$.

COSTA, A.S.; LOBATO, V. Avaliação da presença de resíduos de antimicrobianos em leite e bebida láctea UHT por teste de inibição microbiana comercial. Revista do Instituto de Laticínios Cândido Tostes, Juiz de Fora, v.64, n.368, p.72-76, 2009.

DÜRR, J.W.; CARVALHO, M.P.; SANTOS, M.V. O compromisso coma qualidade do leite no Brasil. Passo Fundo: UPF Press, 2004. $331 \mathrm{p}$.

ECKERT, R.G.; ROMAN, J.A. Perfil dos consumidores de leite do município de Cascavel - Paraná. Varia Scientia, Cascavel, v.10, n. 17, p.137-145, 2010. 
FOLLY, M.M.; MACHADO, S.C.A. Determinação de resíduos de antibióticos, utilizando-se métodos de inibição microbiana, enzimático e imunoensaios no leite pasteurizado comercializado na região norte do Estado do Rio de Janeiro. Ciência Rural, Santa Maria, v.31, n.1, p.95-98, 2001.

FRANCO, B.D.G.M.; LANDGRAF, M. Microbiologia dos Alimentos. São Paulo: Atheneu, 2008. 182p.

GUIMARÃES, F.F.; LANGONI, H. Leite: alimento imprescindível, mas com risco a saúde pública. Veterinária e Zootecnia, Botucatu, v.16, n.1, p.38-51, 2009.

INSTITUTO BRASILEIRO DE GEOGRAFIA E ESTATÍSTICA (IBGE). Mapas estatísticos dos setores censitários. 2010. Available from: <http://downloads.ibge.gov.br/downloads_geociencias.htm>. Accessed on: 2012 October.

LE LOIR, Y.; BARON, F.; GAUTIER, M. Staphylococcus aureus and food poisoning. Genetics and Molecular Research, Ribeirão Preto, v.2, n. 1, p.63-76, 2003.

LENHARO, M.; COUTINHO, F. Grupo é acusado de pôr formol em leite. Folha de S.Paulo, p.C1-C3, May 09 2013. Cotidiano. Available from: <http://acervo.folha.com.br/fsp/2013/05/09/15//5871429>. Accessed on: 2016 May.

LIRO, C.V.; GRANJA, R.E.P.; ZOCCHE, F. Perfil do consumidor de leite no Vale do Rio São Francisco, Pernambuco. Ciência Animal Brasileira, Goiânia, v.12, n.4, p.7 18-726, 2011.

MATOS, E. TJ mantém condenação de envolvidos na fraude do leite. Gaúcha, 16 jun. 2017. Available from: <http://gaucha.clicrbs. com.br/rs/noticia-aberta/tj-mantem-condenacao-de-envolvidosna-fraude-do-leite-198195.html>. Accessed on: 2017 Aug.

MENDES, C.G.; SAKAMOTO, S.M.; SILVA, J.B.A.; JÁCOME, C.G.M.; LEITE, A.I. Análises físico-químicas e pesquisa de fraude no leite informal comercializado no município de Mossoró, RN. Ciência Animal Brasileira, Goiânia, v. 1 1, n.2, p.349-356, 2010.

MILIOTTIS, M.D.; BIER, J.W. International Handbook of Food borne Pathogens. Nova York: Marcel Dekker, 2003. 830p.

MOTTA, R.G.; SILVA, A.V.; GIUFFRIDA, R.; SIQUEIRA, A.K.; PAES A.C.; MOTTA, I.G.; LISTONI, F.J.P.; RIBEIRO, M.G. Indicadores de qualidade e composição de leite informal comercializado na região Sudeste do Estado de São Paulo. Pesquisa Veterinária Brasileira, v.35, n.5, p.417-423, 2015.

NERO, L.A.; DE MATTOS, M.R.; BELOTI, V.; BARROS, M.A.F.; PONTES NETTO, D.; PINTO, J.P.A.N.; DE ANDRADE, N.J.; SILVA, W.P.; FRANCO, B.D.G.M. Hazards in non-pasteurized Milk on retail sale in Brazil: Prevalence of Salmonella spp., Listeria monocytogene sand chemical residues. Brazilian Journal of Microbiology, São Paulo, v.35, p.211-215, 2004.
NERO, L.A.; MAZIERO, D.; BEZERRA, M.M.S. Hábitos alimentares do consumidor de leite cru de Campo Mourão - PR. Semina, Londrina, v.24, n.1, p.21-26, 2003.

ORDÓÑEZ PEREDA, J.A.; RODRÍGUEZ, M.I.C.; ÁLVAREZ, L.F.; SANZ, M.L.G.; MINGUILLÓN, G.D.G.F.; PERALES, L.H.; CORTECERO, M.D.S. Tecnologia de Alimentos - Alimentos de Origem Animal. Porto Alegre: Artmed, 2005. v.2. 279p.

PIERI, F.A.; COLOMBO, M.; MERHI, C.M.; JULIATI, V.A.; FERREIRA, M.S.; NERO, M.A.; NERO, L.A. Risky Consumption Habits and Safety of Fluid Milk Available in Retail Sales Outlets in Viçosa, Minas Gerais State, Brazil. Foodborne Pathogens and Diseases, New Rochelle, v.11, n.6, p.490-496, 2014.

SANTOS, M.V.; FONSECA, L.F.L. Estratégias para controle da mastite e melhoria da qualidade do leite. Barueri: Manole, 2007. 328p.

SILVA JÚNIOR, F.F.; MEGID, J.; NOZAKI, C.N.; PINTO, J.P.A.N. Avaliação do teste do anel em leite na vigilância epidemiológica da brucelose bovina em rebanhos e em laticínios. Arquivo Brasileiro de Medicina Veterinária e Zootecnia, Belo Horizonte, v.59, n.2, p.295-300, 2007.

SOARES, K.M.P.; GÓIS, V.A.; AROUCHA, E.M.M.; VERÍSSIMO, A.M.O.T.; SILVA, J.B.A. Hábitos de consumo de leite em três municípios do Estado do Rio Grande do Norte. Verde Agroecologia e Desenvolvimento Sustentável, Pombal,v.5, n.3, p. $160-164,2010$.

SOVINSKI, A.I.; CANO, F.G.; RAYMUNDO, N.K.L.; BARCELLOS, V.C.; BERSOT, L.S. Situação da comercialização do leite cru informal e avaliação microbiológica e físico-química no município de Cafelândia, Paraná, Brasil. Arquivos de Ciência Veterinária e Zoologia, Umuarama, v.17, n.3, p.161-165, 2014.

SWAI, E.S.; SCHOOMANN, L. Microbial quality and associated health risks of raw milk marketed in the Tanga region of Tanzania. Asian Pacific Journal Tropical Biomedicine, Hainan, v. 1, n.3, p.217-222, 2011

VIEIRA, T.S.W.J.; RIBEIRO, M.R.; NUUNES, M.P.; MACHINSKI JÚNIOR, M.; PONTES NETTO, D. Detecção de resíduos de antibióticos em amostras de leite pasteurizado do Estado do Paraná, Brasil. Semina, Londrina, v.33, n.2, p.791-196, 2012.

VILLA, F.B.; PINTO, J.P.A.N. Qualidade físico-química, microbiológica e presença de resíduos de antimicrobianos no leite in natura comercializado informalmente em Brotas, SP. Higiene Alimentar, Mirandópolis, v.22, n.158, p.98-103, 2008.

WALSTRA, P.; WOUTERS, J.T.M.; GEURTS, T.J. Dairy Science and Technology. 2. ${ }^{a}$ ed. Nova York: Taylor \& Francis Group, 2005. $781 \mathrm{p}$. 